\title{
Odnos tiska prema Katoličkoj Crkvi u Jugoslaviji u razdoblju od 1952. do 1970. godine - na primjeru analize vinkovačkoga lista Novosti
}

\author{
IVANA BENDRA* \\ - https://doi.org/10.31823/d.29.2.6 \\ UDK: 070:272(497.1)“1952/1970“ • Prethodno priopćenje \\ Primljeno: 28. srpnja 2020. • Prihvaćeno: 27. svibnja 2021.
}

* Dr. sc. Ivana Bendra,

Institut društvenih znanosti Ivo Pilar, Područni centar Vukovar,

J.J. Strossmayera 25, p. p. 58,32000 Vukovar, Hrvatska, Ivana.Bendra@pilar.hr

Sažetak: Složenost odnosa jugoslavenske komunističke vlasti prema Katoličkoj Crkvi u okviru stvaranja novoga socijalističkoga društveno-političkoga uređenja tema je o kojoj će se u ovom radu progovoriti na temelju analize odnosa tiska prema Katoličkoj Crkvi u razdoblju od 1952. do 1970. godine. Na primjeru provedene kvantitativno-kvalitativne analize članaka objavljenih u vinkovackkom listu Novosti $u$ odabranom razdoblju prikazat će se rezultati o učestalosti pojavljivanja, kao $i$ kontekst $u$ okviru kojega su se pojavljivale odabrane ključne riječi za analizu digitaliziranoga oblika novina (Katolička Crkva, svećenici, religija/religioznost, kler/klerikalizam, crkva, vjera, kršćanstvo). Na taj način cilj je analize tjednika Novosti utvrditi uočavaju li se određene promjene u odnosu tiska prema Katoličkoj Crkvi u razdoblju dugom devetnaest godina za vrijeme kojega se odvilo više događanja ključnih za propitivanje sveukupnoga odnosa Jugoslavije prema Katoličkoj Crkvi (od prekida diplomatskih odnosa izmedu Svete stolice i Jugoslavije, potpisivanja Protokola, sve do ponovne uspostave diplomatskih odnosa).

Ključne riječi: Katolička Crkva, tisak, vinkovački list Novosti, Jugoslavija, kvantitativno-kvalitativna analiza sadržaja.

\section{Uvod}

Po završetku Drugoga svjetskoga rata 1945. godine i komunističkoga preuzimanja vlasti u okviru novonastale socija- 
lističke Jugoslavije Katolička Crkva suočavala se s primjenom represivne politike kojom je jugoslavenska vlast htjela dovesti do »potpunog onemogućavanja (eliminiranja) svih faktora koji su na bilo koji način mogli imati negativan utjecaj na ostvarenje potpune indoktrinacije njezinih građana u skladu s novonastalim društvenim uređenjem «. ${ }^{1}$ Pod optužbom za suradnju s okupatorom, ustaškim režimom, ${ }^{2}$ nad predstavnicima Katoličke Crkve uslijedio je teror, a uz počinjenja mnogobrojnih zločina nad predstavnicima te vjerske zajednice ${ }^{3}$ nova je komunistička vlast uvela $\mathrm{i}$ potpunu kontrolu svih njezinih aktera te gotovo u potpunosti onemogućila znatan dio njezinih aktivnosti. Uz ukidanje vjeronauka u školama, vjerskoga tiska, zatvaranje dijela vjerskih škola, zabranu javnoga prakticiranja vjerskih običaja i blagdana te napuštanje klera teritorija Jugoslavije doneseno je i više zakona kojima se pokušalo utjecati i na potpuno materijalno oslabljivanje Katoličke Crkve. ${ }^{4}$

Promjena taktike jugoslavenske vlasti u odnosu prema Katoličkoj Crkvi, koja je uslijedila 50-ih godina, a koja se zasnivala na primjeni $\gg$ političkih sredstava $\ll^{5} \mathrm{u}$ suzbijanju njezina utjecaja u društvu, bila je »usmjerena prvenstveno jugoslavenskim vanjskopolitičkim interesima $\ll{ }^{6}$ i nastojanjima da se $\gg$ izbjegnu neželjeni učinci daljnje primjene represivne politike prema Katoličkoj crkvi $\ll^{7}$. Otvoreno kršenje vjerskih sloboda zamjenjuje se »politikom otvaranja procesima demokratizacije jugoslavenskoga društva $\ll^{8}$ te je 1953. godine donesen i Zakon o pravnom položaju vjerskih zajednica. Zakonom koji je u sebi sadržavao osnovna pravna načela - slobodu savjesti, slobodu vjeroispovijesti i odvojenosti države od Crkve ${ }^{9}$ - nastojalo se prikazati jugoslavensko društvo kao društvo u kojem su »odnosi između države i vjerskih zajednica potpuno normalizirani $\ll^{10}$, odnosno da je jugoslavensko socijalističko društvo »zainteresirano za učešće svih ljudi u procesima izgradnje

\footnotetext{
${ }^{1}$ I. BENDRA, D. ŽIVIĆ, P. ELEZ, Položaj vjerskih zajednica u Općini Vinkovci (1964. - 1975.), Vukovar, 2019., 11.; Usp. S. CVIKIĆ, Vukovar u drugoj polovici 20. stoljeća: društveni uzroci nasilja, Doktorski rad, Zagreb, 2016.

${ }^{2}$ E. ĆIMIĆ, Država i konfesionalne zajednice u Jugoslaviji, u: Politička misao 2(1967.)4, 155-165., ovdje 157.

${ }^{3} \mathrm{O}$ razmjerima zločina vidjeti u: K. BOECKH, Vjerski progoni u Jugoslaviji 1944. - 1953.: staljinizam u titoizmu, u: Časopis za suvremenu povijest 2(2006.)38, 403-431.

${ }^{4}$ Više o donesenim zakonima vidjeti u: M. AKMADŽA, Katolička crkva u komunističkoj Hrvatskoj 1945. - 1980., Zagreb - Slavonski Brod, 2013., 49-62.

${ }^{5}$ M. AKMADŽA, Katolička crkva u komunističkoj Hrvatskoj 1945. - 1980., 165.

${ }^{6}$ I. BENDRA, D. ŽIVIĆ, P. ELEZ, Položaj vjerskih zajednica u Općini Vinkovci (1964. - 1975.), 12.

${ }^{7}$ M. AKMADŽA, Katolička crkva u komunističkoj Hrvatskoj 1945. - 1980., 165.

${ }^{8}$ Usp. E. ĆIMIĆ, Država i konfesionalne zajednice u Jugoslaviji, 160.

${ }^{9}$ Usp. isto.

${ }^{10}$ I. BENDRA, D. ŽIVIĆ, P. ELEZ, Položaj vjerskih zajednica u Općini Vinkovci (1964. - 1975.), 248.
} 
novoga društva, bez obzira na njihov odnos prema religiji $\ll .{ }^{11} \mathrm{U}$ Programu SKH-a iz 1958. također se navodi kako je »marksizam, kao pogled na svet i idejna osnova praktične delatnosti komunista, nespojiv sa bilo kakvim religioznim ubeđenjima «, no $\gg($... komunisti $u$ isto vreme poštuju pravo građana Jugoslavije da pripadaju ili ne pripadaju jednoj od verskih zajednica priznatih Ustavom i zakonima, kao i da praktički vrše svoje religiozne običaje i da zbog svojo religioznog ubeđenja i vršenja religioznih običaja ne snose nikakve posljedice u svojim društvenim i političkim pravima $\ll^{12}$.

$\mathrm{U}$ isto vrijeme, koje se u javnosti nastojalo prikazati kao početak tzv. normalizacije odnosa te vjerske zajednice i države, ${ }^{13}$ zbog tobožnjega miješanja u unutarnje uređenje jugoslavenskih religijsko-državnih odnosa, 1952. godine prekinuti su diplomatski odnosi između Jugoslavije i Svete stolice. ${ }^{14}$ Razlog navedenom jest činjenica da je tu fazu u odnosu između države i vjerskih zajednica u okviru novoga socijalističkoga društveno-političkoga uređenja, započetu 50-ih godina prošloga stoljeća, u stvarnosti karakterizirala primjena suptilnijih metoda kontrole aktivnosti Katoličke Crkve radi nastavka poduzimanja aktivnosti koje bi dovele do potpuna onemogućavanja bilo kakva utjecaja njezinih predstavnika na razvitak novonastaloga društvenoga uređenja. U tomu je važnu ulogu imalo osnivanje Staleškoga društva katoličkih svećenika kojima je nova komunistička vlast željela postići »razbijanje jedinstva Katoličke Crkve $\ll^{15}$, a suradnju katoličkih svećenika s novom vlašću nastojala je postići privlačeći ih na učlanjenje raznim povlasticama. ${ }^{16}$ Upravo je dakle osnivanje Staleškoga društva katoličkih svećenika, kojim se željelo stvoriti »narodnu crkvu «, odvojenu od Svete stolice ${ }^{17}$, bio razlog za prekid jugoslavenske vlade diplomatskih odnosa sa Svetom stolicom. ${ }^{18}$

${ }^{11}$ E. ĆIMIĆ, Država i konfesionalne zajednice u Jugoslaviji, 163.

${ }^{12}$ Program Saveza komunista Jugoslavije, usvojen na Sedmom kongresu Saveza komunista Jugoslavije 22. - 26. aprila 1958., Beograd, 1980., 252.

${ }^{13}$ Usp. E. ĆIMIĆ, Država i konfesionalne zajednice u Jugoslaviji.

${ }^{14}$ M. AKMADŽA, Uzroci prekida diplomatskih odnosa između Vatikana i Jugoslavije 1952. godine, u: Croatica Christiana periodica 52(2003.)27, 171-202., ovdje 171.

${ }^{15}$ M. AKMADŽA, Pregovori Svete Stolice i Jugoslavije i potpisivanje Protokola iz 1966. godine, u: Časopis za suvremenu povijest 2(2004.)36, 473-503., ovdje 473. Za detaljnije informacije o važnosti Društva katoličkih svećenika na vinkovačkom području vidjeti u: I. BENDRA, D. ŽIVIĆ, P. ELEZ, Položaj vjerskih zajednica u Općini Vinkovci (1964. -1975.).

${ }^{16}$ K. BOECKH, Vjerski progoni u Jugoslaviji 1944. - 1953.: staljinizam u titoizmu, 423-424.

${ }^{17}$ M. AKMADŽA, Pregovori Svete Stolice i Jugoslavije i potpisivanje Protokola iz 1966. godine, 473474.

${ }^{18}$ M. AKMADŽA, Uzroci prekida diplomatskih odnosa između Vatikana i Jugoslavije 1952. godine, 171. 
Događaje koji su uslijedili tijekom 60 -ih godina prošloga stoljeća, kada se intenzivira prestanak primjene $\gg$ administrativnih mjera te započinje razdoblje kooperativnosti i politički tolerantnijeg odnosa prema vjerskim zajednicama $\ll{ }^{19}$, jugoslavenske su vlasti pravdale smrću »glavnih krivaca za loše crkveno-državne odnose «, pape Pija XII. i kardinala Alojzija Stepinca. ${ }^{20}$ Daljnji tijek normalizacije odnosa rezultirao je potpisivanjem Protokola 1966. godine između Svete stolice i Socijalističke Federativne Republike Jugoslavije (dalje: SFRJ), odnosno 1970. godine ponovnom uspostavom diplomatskih odnosa. Međutim, unatoč tomu što su se ti događaji smatrali prekretnicom u sređivanju odnosa između Katoličke Crkve i jugoslavenske vlade, većina jugoslavenskih biskupa držala je Protokol motiviranim više vanjskopolitičkim nego unutarpolitičkim interesima jugoslavenske vlasti, ${ }^{21}$ odnosno smatrala je da će se problem svakodnevnoga rada predstavnika Katoličke Crkve s vjernicima, posebice usmjeren zaključcima Drugoga vatikanskoga koncila, i dalje nastaviti. ${ }^{22}$

Kada promotrimo dosadašnje uopćene zaključke o ulozi tiska tijekom spomenutih događanja, odnosno o položaju medija u okviru socijalističke Jugoslavije, uočava se zaključak K. Spehnjak da su novine 50-ih godina prošloga stoljeća služile kao »sredstvo indoktrinacije te bile u službi prenošenja službenih stajališta narodnoj masi $\ll^{23}$. Također Mihaljević zaključuje da su unatoč $\gg$ nominalno i zakonodavno propagiranom načelu slobode medija « cenzura i autocenzura obilježje kontrole medija sve do 60-ih godina prošloga stoljeća, kada započinje $\gg$ krhki proces njihove liberalizacije $\ll .{ }^{24}$ Međutim i tijekom razdoblja ograničene liberalizacije medija, koja je trajala do početka 70 -ih, mediji su imali ulogu $\gg$ promoviranja vladajuće ideologije «, odnosno bili su usklađeni s Programom SKJ-a i stavom jugoslavenskoga predsjednika Josipa Broza Tita da tisak služi stvaranju socijalističkoga čovjeka. ${ }^{25}$

${ }^{19}$ Usp. S. ZRINŠČAK, Odnos Crkve i države u Hrvatskoj od 1945. - 1990. godine, u: I. GRUBIŠIĆ i dr. (prir.), Split, 1993., ovdje 114-119.; I. BENDRA, D. ŽIVIĆ, P. ELEZ, Položaj vjerskih zajednica u Općini Vinkovci (1964. - 1975.), 252.

${ }^{20}$ M. AKMADŽA, Pregovori Svete Stolice i Jugoslavije i potpisivanje Protokola iz 1966. godine, 474.

${ }^{21}$ Usp. S. ZRINŠČAK, Odnos Crkve i države u Hrvatskoj od 1945. - 1990. godine, 117.

${ }^{22}$ Usp. I. BENDRA, D. ŽIVIĆ, P. ELEZ, Položaj vjerskih zajednica u Općini Vinkovci (1964. - 1975.), 137-184.

${ }^{23}$ K. SPEHNJAK, Uloga novina u oblikovanju javnog mnijenja u Hrvatskoj 1945. - 1952., u: Časopis za suvremenu povijest 2-3(1993.)25, 165-181., ovdje 168.

${ }^{24}$ J. MIHALJEVIĆ, Liberalizacija i razvoj medija u komunističkoj Hrvatskoj 1960-ih i na početku 1970-ih, u: Društvena istraživanja 2(2015.)24, 239-258., ovdje 241.

${ }^{25}$ Usp. isto. 


\section{Metodologija istraživanja}

S obzirom na spomenuta događanja u promatranom razdoblju koja se tiču tijeka odnosa jugoslavenskoga društva prema Katoličkoj Crkvi te navedene funkcije tiska u okviru stvaranja socijalističkoga jugoslavenskoga društveno-političkoga uređenja, cilj je ovoga rada prikazati uočavaju li se određene promjene u odnosu tiska prema Katoličkoj Crkvi u odabranom razdoblju od 1952. do 1970. godine. Rezultati istraživanja temelje se na provedenoj kvantitativno-kvalitativnoj analizi sadržaja vinkovačkoga lista, tjednika Novosti. Osvjetljavajući na taj način stvarni položaj Katoličke Crkve u razdoblju dugom devetnaest (19) godina, u ovom radu prikazat će se rezultati analize digitaliziranoga oblika novina Novosti koja je provedena pretragom sljedećih ključnih riječi i njihovih izvedenica: Katolička Crkva / katolici, kršćanstvo, vjera, svećenici, kler, crkva, sloboda vjeroispovijesti. U tom kontekstu postavljena je hipoteza da članci vinkovačkoga lista Novosti prema sadržaju i učestalosti pojavljivanja onih u kojima se uočavaju pretraživani ključni pojmovi ne pokazuju nikakvu promjenu u odnosu tiska prema Katoličkoj Crkvi u istraživanom razdoblju.

Kvantitativni dio analize tjednika Novosti proveden je pretraživanjem digitaliziranoga oblika novina, tijekom koje je pretraženo pojavljivanje ključnih pojmova u svim objavljenim brojevima u razdoblju od 1952. do 1970. godine, ukupno 943 broja. U rezultatima kvantitativnoga dijela istraživanja predstavit će se promjene u odnosu tjednika Novosti prema Katoličkoj Crkvi na temelju prikaza rezultata o učestalosti pojavljivanja ključnih pojmova u člancima te evidentiranim promjenama u učestalosti njihova pojavljivanja.

Uz iznošenje rezultata kvantitativne analize o učestalosti pojavljivanja ključnih pojmova u odabranom razdoblju promjene u odnosu lista Novosti prema Katoličkoj Crkvi prikazat će se i na temelju prikaza rezultata kvalitativne analize sadržaja članaka kojima će se upozoriti na kontekst pojavljivanja ključnih pojmova u odabranom razdoblju.

\section{Rezultati kvantitativne analize članaka vinkovačkoga lista Novosti - učestalost pojavljivanja članaka tematski vezanih uz Katoličku Crkvu}

Kao što se uočava iz priloženoga Grafikona 1, rezultati kvantitativne analize članaka vinkovačkoga lista Novosti u odabranom razdoblju u ukupnom trajanju od devetnaest godina (1952. - 1970.) pokazali su kako je ukupan broj članaka u kojima se pojavljuju pretraživani pojmovi 376 članka. S obzirom na to da se u pojedinim člancima istovremeno pojavljuje više odabranih ključnih pojmova, ukupan broj pojavljivanja pretraživanih pojmova jest 481 put. 
GRAFIKON 1. Prikaz ukupnoga broja pojavljivanja članaka prema zadanim kriterijima u vinkovačkom listu Novosti za razdoblje od 1952. do 1970. godine

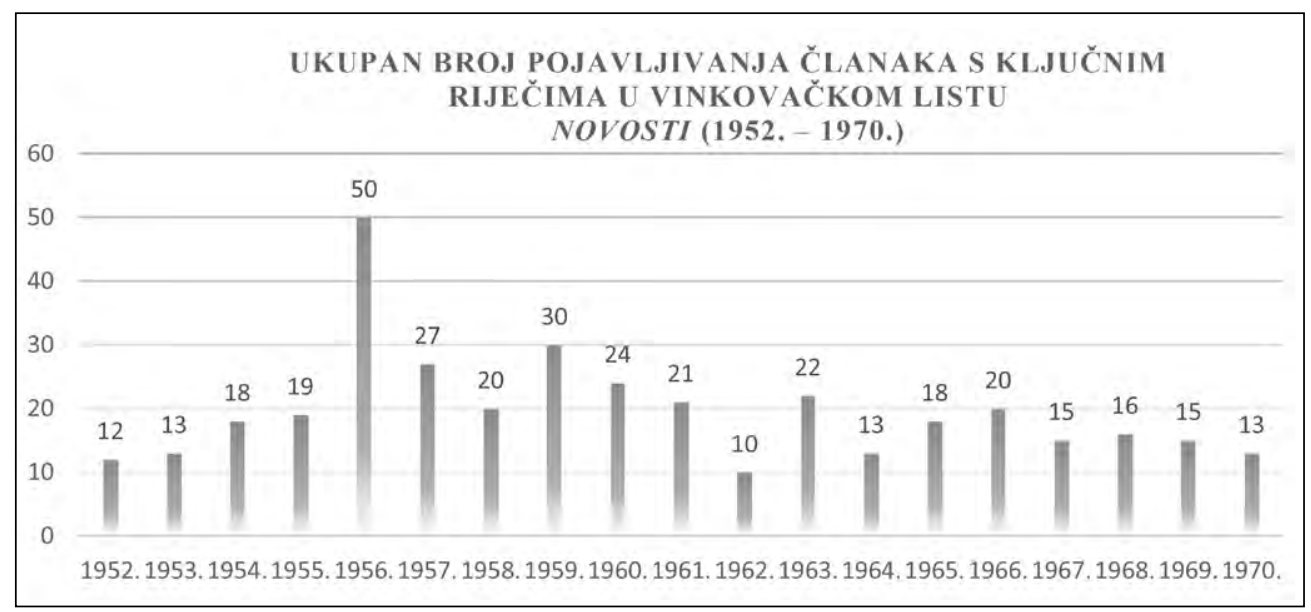

Isto tako na temelju rezultata kvantitativne analize o broju članaka u analiziranom razdoblju moguće je zaključiti da se uočava određena konstanta u učestalosti njihova pojavljivanja, osim u razdoblju od 1956. godine, kada imamo najveći broj članaka, pa sve do 1959. godine, do kada je uočeno blago povećanje broja članaka u kojima se pojavljuju pretraživani pojmovi.

GRAFIKON 2. Prikaz ukupnoga broja pojavljivanja ključnih pojmova u vinkovačkom listu Novosti za razdoblje od 1952. do 1970. godine

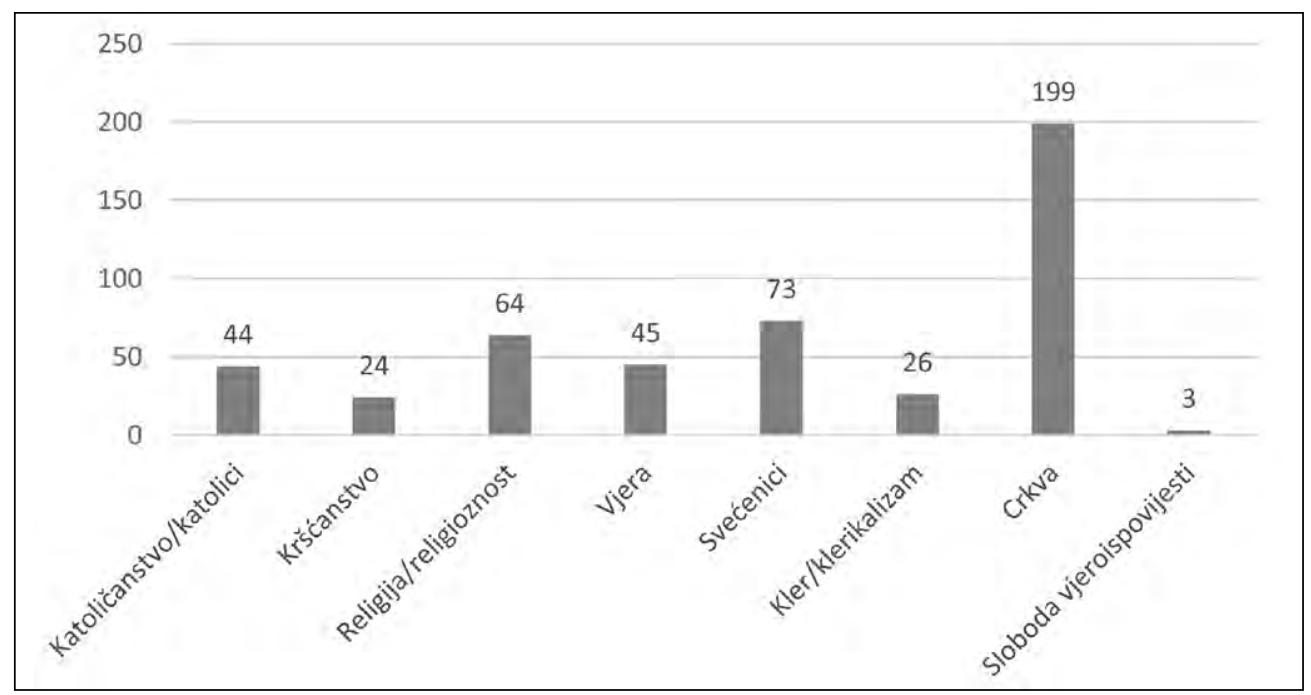


Na temelju uvida u prikazane podatke u Grafikonu 2, a koji se odnose na pojedinačan prikaz rezultata kvantitativne analize o ukupnom pojavljivanju pretraživanih ključnih pojmova u odabranom razdoblju, može se uočiti kako se u člancima najučestalije pojavljuje pojam crkva, u ukupno 199 članaka. Potom slijedi pojam svećenici s ukupnim pojavljivanjem u 73 članka, pojam religija/religioznost u 64 član$\mathrm{ka}$, pojam vjera u 45 članaka, pojam katoličanstvo/katolici u 44 članka, pojam kler/ klerikalizam u 26 članaka te pojam kršćanstvo u 24 članka. Najrjeđe pojavljivanje među pretraživanim pojmovima uočeno je kod pojma sloboda vjeroispovijesti koji se u promatranom razdoblju pojavljuje u svega 3 članka.

GRAFIKON 3. Prikaz ukupnoga broja pojavljivanja članaka u vinkovačkom listu Novosti za razdoblje od 1952. do 1970. godine prema ključnoj riječi religija/religioznost

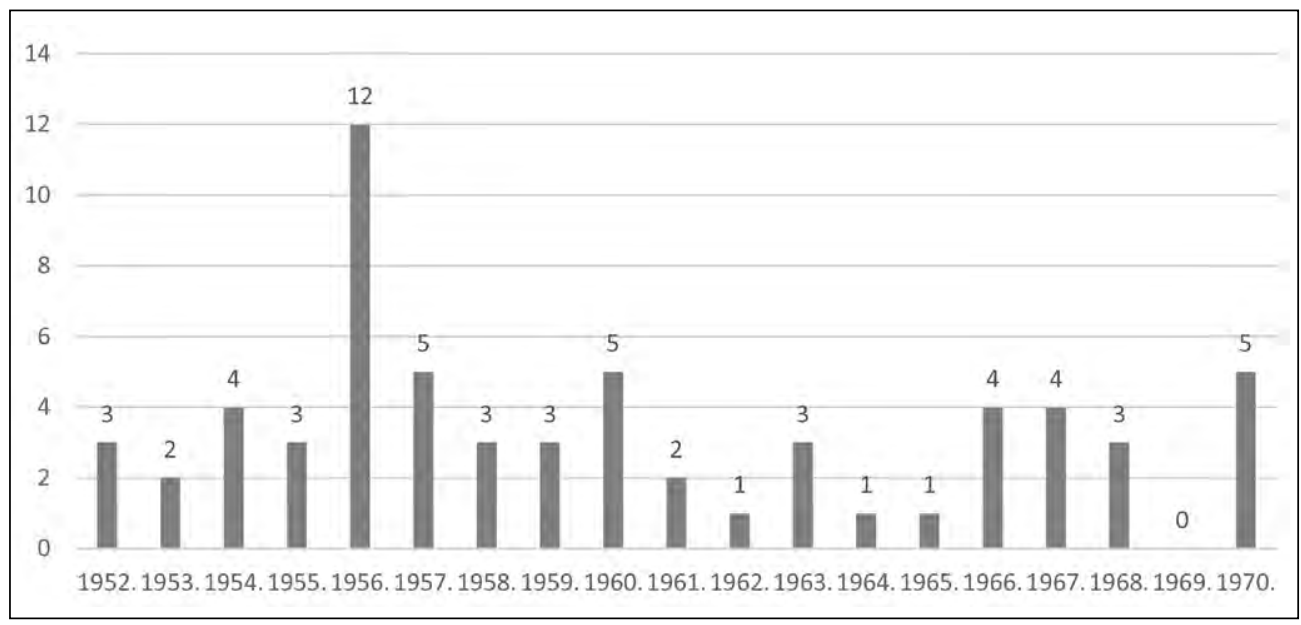

Također rezultati pojedinačne analize o učestalosti pojavljivanja odabranih ključnih pojmova pokazuju da se pojam religija/religioznost u kontinuitetu godišnje najučestalije pojavljivao između 1 i 5 puta, osim nešto učestalijega pojavljivanja tijekom 1956. godine, kada se taj pojam pojavljuje 12 puta (Grafikon 3).

Sljedeći analizirani pojam crkva ili Crkva (crkvenost, crkveni i sl.), koji se među analiziranim ključnim riječima najučestalije pojavljivao te je uočen u ukupno 199 članaka, također karakterizira određena konstanta u učestalosti pojavljivanja u najvećem dijelu promatranoga razdoblja. Najučestalije se taj pojam godišnje pojavljivao između 6 i 11 puta. Također se ponovno uočava učestalije pojavljivanje tijekom 1956. godine, uz blago povećanje u učestalosti pojavljivanja sve do 1961. godine (Grafikon 4). 
GRAFIKON 4. Prikaz ukupnoga broja pojavljivanja članaka u vinkovačkom listu Novosti za razdoblje od 1952. do 1970. godine prema ključnoj riječi crkva/crkveni

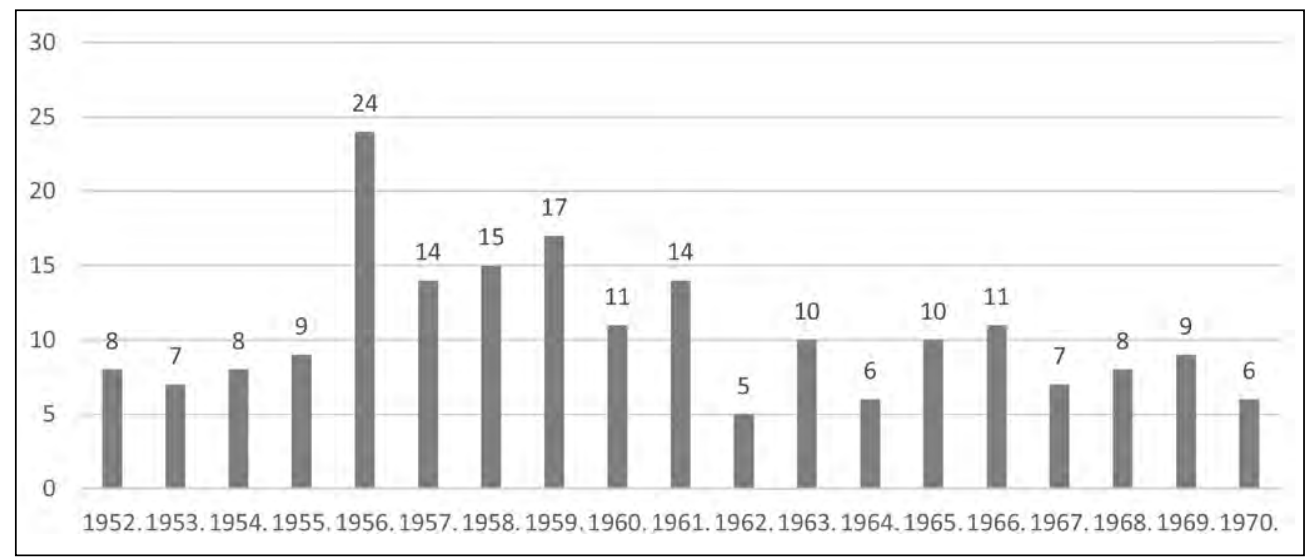

GRAFIKON 5. Prikaz ukupnoga broja pojavljivanja članaka u vinkovačkom listu Novosti za razdoblje od 1952. do 1970. godine prema ključnoj riječi svećenici

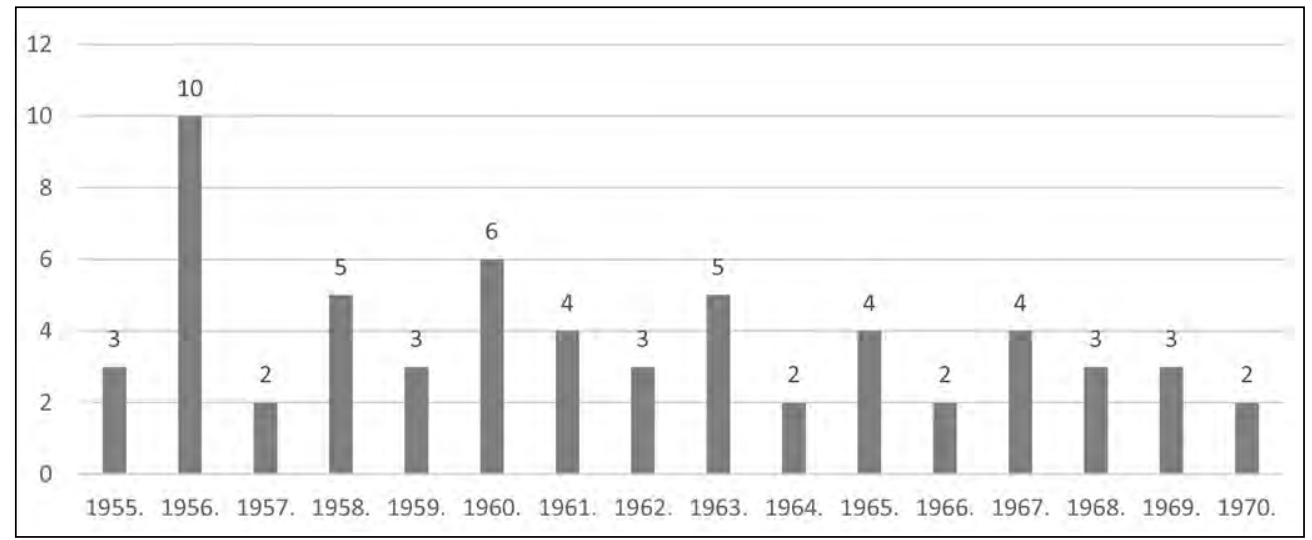

Pretraživani pojam svećenici, kao što je vidljivo iz priloženoga Grafikona 5, pojavljuje se u odabranom razdoblju u ukupno 73 članka. Pojavljivanje toga ključnoga pojma također karakterizira konstanta u učestalosti pojavljivanja (između 2 i 6 puta godišnje), uz ponovno učestalije pojavljivanje tijekom 1956. godine (10 puta). 
GRAFIKON 6. Prikaz ukupnoga broja pojavljivanja članaka u vinkovačkom listu Novosti za razdoblje od 1952. do 1970. godine prema ključnoj riječi kler

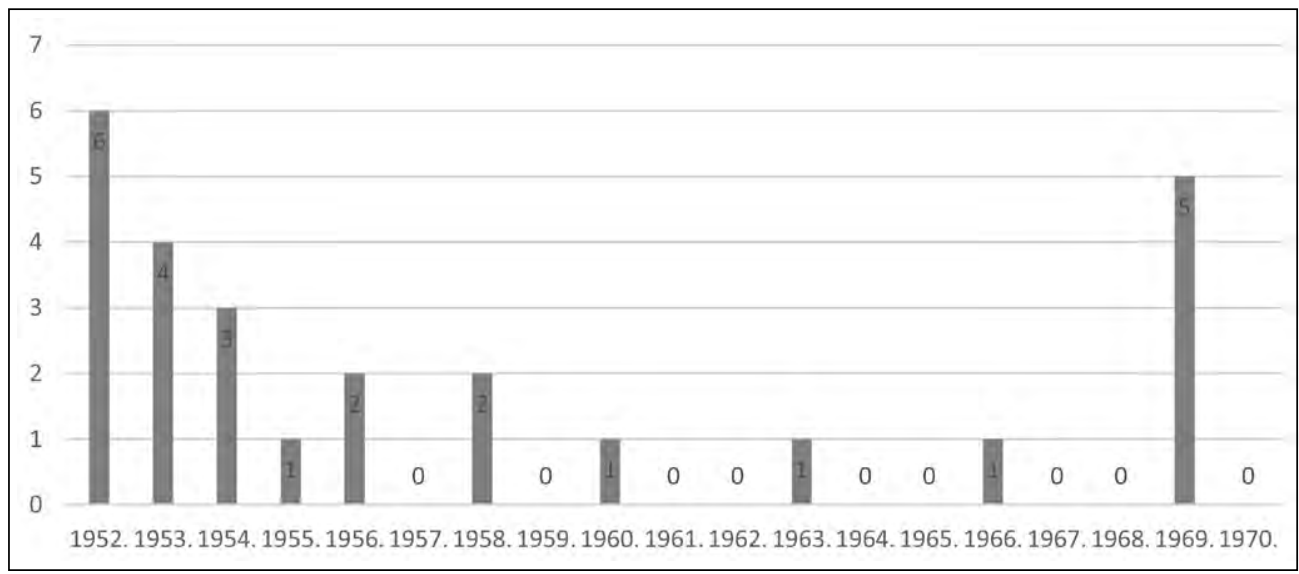

Kao što se može vidjeti iz priloženoga Grafikona 6, pojam kler, odnosno klerikalizam, u odabranom razdoblju pojavljuje se u ukupno 26 članaka. Ono što se iz priloženoga grafikona dodatno uočava jest intenzivnije pojavljivanje tih pojmova u prvoj godini promatranoga razdoblja te, nakon duljega niza pojavljivanja pretraživanih pojmova jednom ili ni jednom godišnje, njihovo učestalije pojavljivanje tijekom 1969. godine.

GRAFIKON 7. Prikaz ukupnoga broja pojavljivanja članaka u vinkovačkom listu Novosti za razdoblje od 1952. do 1970. godine prema ključnim riječima sloboda vjeroispovijesti

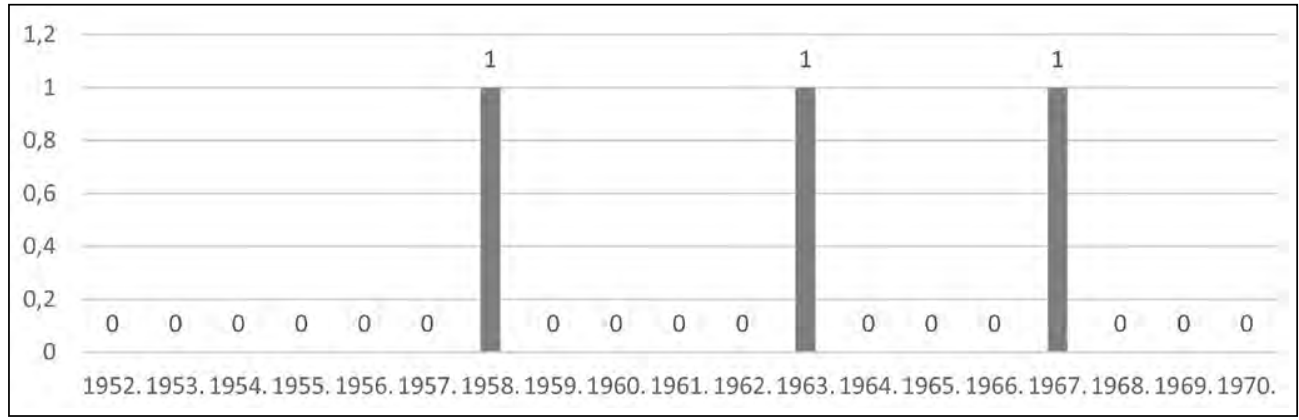

Nadalje, kao što je vidljivo iz priloženoga Grafikona 7, ključni pojam sloboda vjeroispovijesti jest pojam koji se među istraživanim najrjeđe pojavljuje, odnosno u većini godina ne pojavljuje se ni u jednom članku te je njegovo pojavljivanje u pretraživanom razdoblju uočeno u svega 3 članka. 
GRAFIKON 8. Prikaz ukupnoga broja pojavljivanja članaka u vinkovačkom listu Novosti za razdoblje od 1952. do 1970. godine prema ključnoj riječi vjera

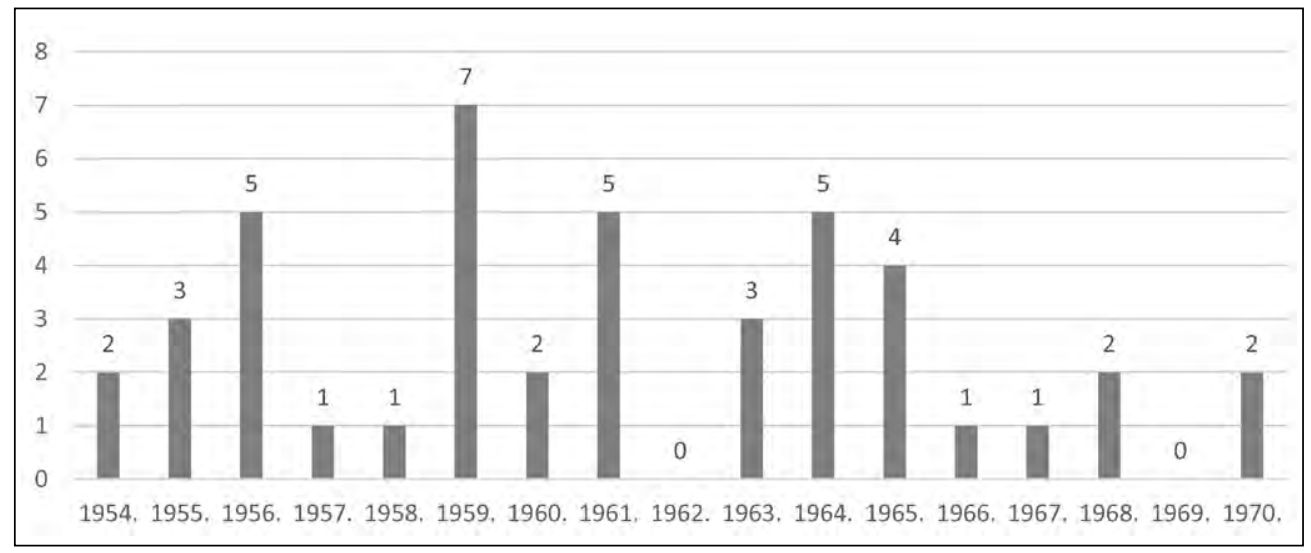

Sljedeći istraživani pojam, čiji su rezultati istraživanja prikazani u Grafikonu 8, jest pojam vjera (vjernici, vjeronauk). Taj se pojam u istraživanom razdoblju pojavljuje u ukupno 45 članaka, s najučestalijim godišnjim pojavljivanjem u jednom do pet članaka.

GRAFIKON 9. Prikaz ukupnoga broja pojavljivanja članaka u vinkovačkom listu Novosti za razdoblje od 1952. do 1970. godine prema ključnoj riječi kršćanstvo

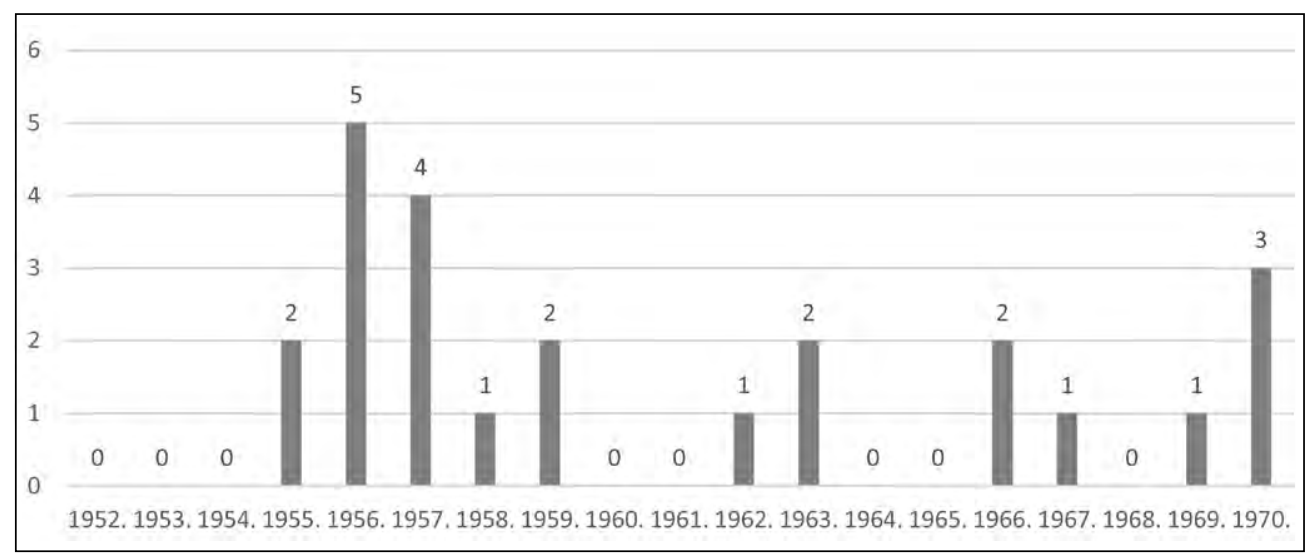

Pojam kršćanstvo, kao što je vidljivo iz priloženoga Grafikona 9, pojavljuje se u analiziranom razdoblju u svega 24 članka, gdje je uočeno najučestalije godišnje pojavlivanje u jednom ili dvama člancima. 
GRAFIKON 10. Prikaz ukupnoga broja pojavljivanja članaka u vinkovačkom listu Novosti za razdoblje od 1952. do 1970. godine prema ključnoj riječi

\section{katoličanstvo/katolici}

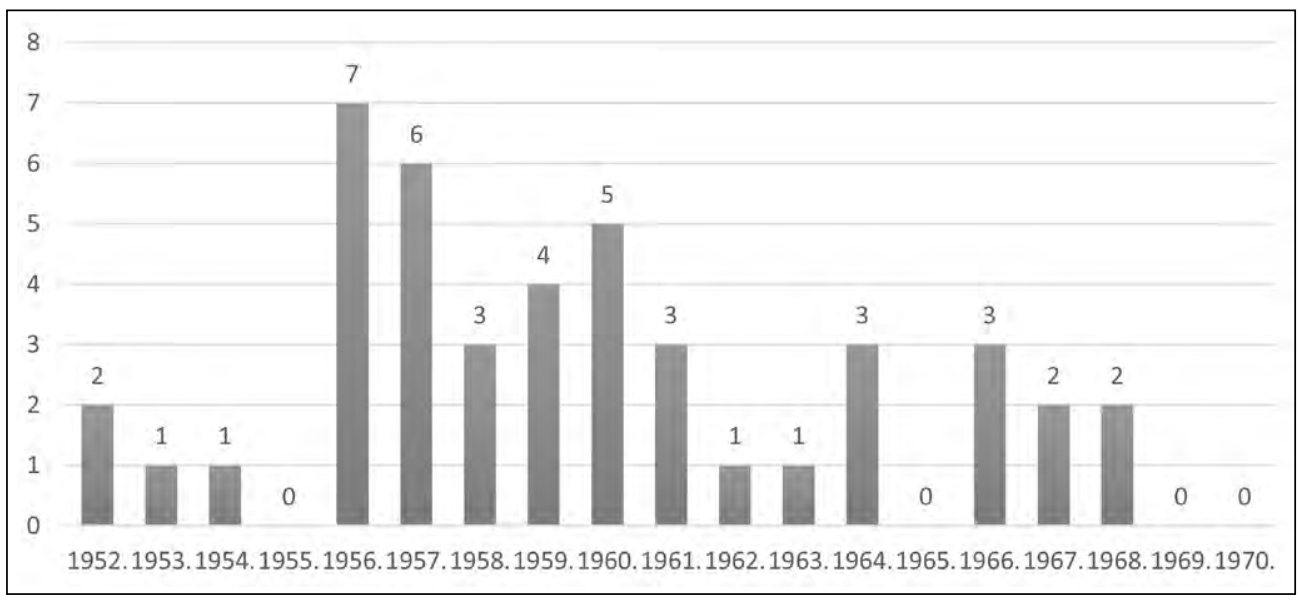

Posljednji analizirani pojam, pojam katoličanstvo, kao što se uočava iz priloženoga Grafikona 10, pojavljuje se u analiziranom razdoblju u ukupno 44 članka, s najučestalijim godišnjim pojavljivanjem u jednom do tri članka.

Na temelju rezultata kvantitativnoga dijela analize sadržaja tjednika Novosti moguće je zaključiti da podatci o broju članaka prema zadanim kriterijima potvrđuju tezu K. Spehnjak o tome kako »komunistička vlast nije zanemarivala javno mnijenje, nego ga je neutralizirala ${ }^{26}{ }^{26}$ jer je vidljivo kako je vinkovački list Novosti, kao javni medij, »gotovo u potpunosti isključio sadržaje s religijskom tematikom iz javnog prostora. $\ll{ }^{27}$ Podatci o učestalosti pojavljivanja odabranih ključnih pojmova u pretraživanom razdoblju, dugom devetnaest godina, također većim dijelom potvrđuju i zadanu hipotezu da se u člancima vinkovačkoga lista Novosti prema učestalosti pojavljivanja ključnih pojmova ne uočavaju nikakve promjene u odnosu tiska prema Katoličkoj Crkvi u istraživanom razdoblju. Većina pretraživanih ključnih pojmova pojavljuje se u kontinuitetu u jednom do pet članaka godišnje, odnosno pojam $\mathrm{cr}$ $\mathrm{kva} /$ crkvenost $\mathrm{u}$ šest do jedanaest članaka. Iznimka je uočena jedino u učestalijem pojavljivanju gotovo svih pretraživanih pojmova 1956. godine (osim pojmova kler, sloboda vjeroispovijesti i vjera). Ono s čime je, na temelju odabranoga izvora podataka za analizu, moguće povezati učestalije pojavljivanje većine odabranih ključnih pojmova 1956. godine jest članak iz iste godine u kojem se progovara o održanom

\footnotetext{
${ }^{26}$ K. SPEHNJAK, Uloga novina u oblikovanju javnog mnijenja u Hrvatskoj 1945.-1952., 168.

${ }^{27}$ Usp. I. BENDRA, D. ŽIVIĆ, P. ELEZ, Položaj vjerskih zajednica u Općini Vinkovci (1964.-1975.), 262.
} 
VI. plenumu CK-a SKJ-a, zbog čega je, kako se navodi, > pojačan rad i koordinacija svih organa vlasti na provođenju zaključaka VI. Plenuma CK SKJ, u svim granama privrednog, političkog, društvenog i kulturnog života $\ll .{ }^{28} \mathrm{Na}$ tragu donesenih zaključaka o intenziviranju aktivnosti u rješavanju aktualnih društvenih problema može se tumačiti i pojačana aktivnost vinkovačkoga lista Novosti te je uočeno uvođenje stalne rubrike, pod nazivom Mali tečaj iz filozofije, u kojoj se redovito obrađivala tematika odnosa marksizma/komunizma i religije te se upravo u tim člancima pojavljuje značajan dio pretraživanih pojmova.

\section{Rezultati kvalitativne analize članaka vinkovačkoga lista Novosti - kontekst pojavljivanja ključnih pojmova}

Kao što je već spomenuto, uz kvantitativnu analizu učestalosti pojavljivanja ključnih pojmova u odabranom razdoblju, radi utvrđivanja promjena u odnosu tiska prema Katoličkoj Crkvi na primjeru vinkovačkoga lista Novosti, provedena je i kvalitativna analiza sadržaja članaka u kojima se pojavljuju ključni pojmovi, odnosno analiza načina izvještavanja i konteksta u okviru kojega se spominju pretraživani pojmovi. U nastavku će se stoga iznijeti rezultati kvalitativne analize za svih osam pretraživanih pojmova, nakon čega će se, u okviru završne rasprave, detaljnije iznijeti doneseni zaključci o odnosu vinkovačkoga lista Novosti prema Katoličkoj Crkvi u promatranom razdoblju.

\subsection{KONTEKST POJAVLJIVANJA KLJUČNOGA POJMA RELIGIJA/RELIGIOZNOST}

Prikaz rezultata kvalitativne analize sadržaja vinkovačkoga lista Novosti započet će se prikazom rezultata za pretraživani pojam religija/religioznost koji se, kao što je već spomenuto, pojavljuje u ukupno 64 članka. Analiza je pokazala kako je članke u okviru kojih se pojavljuju pojmovi religija ili religioznost u najvećem broju moguće okarakterizirati kao članke koji imaju tzv. »funkciju provođenja kulturne i prosvjetne politike $\ll{ }^{29}$ odnosno koji imaju za cilj provedbu protureligijske propagande, čime se potvrđuje da su novine bile $u \gg$ funkciji protureligioznog prosvjećivanja socijalističkog čovjeka $\ll .{ }^{30}$ Sadržaj tih članaka pokazuje kako se komunistička vlast

\footnotetext{
${ }^{28}$ Usp. http://library.foi.hr/vl/broj.aspx?C=10\&godina=1956\&broj=000019\&stranica=001 (4. 11 . 2020.). Rubrika je bila aktualna 1956. i 1957. Međutim 1957. pojavljuje se samo dva puta, za razliku od 1956., kada se pojavila u ukupno pet brojeva.

${ }^{29}$ K. SPEHNJAK, Prosvjetno-kulturna politika u Hrvatskoj 1945. - 1948., u: Časopis za suvremenu povijest 1(1993.)25, 73-98., ovdje 92.

${ }^{30}$ Isto, 93.; I. BENDRA, D. ŽIVIĆ, P. ELEZ, Položaj vjerskih zajednica u Općini Vinkovci (1964. 1975.), 215.
} 
novinama, kao javnim medijem, koristila kako bi u procesu »stvaranja socijalističkog čovjeka « utjecala na njegovo formiranje, u najvećem broju člancima u okviru rubrike Prosvjeta $i$ kultura, kojima se nastojalo religiju prikazati kao nešto nazadno i negativno, kao »filozofiju primitivaca $\ll^{31}$, gdje se kroz govor o prošlim običajima, utjecaju religije na umjetnost ili društveni razvitak i uređenje religija predstavlja kao proizvod prošlosti. U tom smislu izdvojit će se citat iz jednoga od serije članaka pod nazivom Mali tečaj iz filozofije - Filozofija religije u socijalizmu iz 1956. godine:

$\gg$ Socijalizam je najviša faza ljudskog zbližavanja u razvitku savremenog čovječanstva. Što su ljudske zajednice opterećenije, a mnoštvo teških suprotnosti raznolikije, uslovi za revoluciju su povoljniji i njeno je tada dozrijevanje brže. Nužno je $k$ ovome potreban izvjestan nivo materijalnog razvoja a ideološka svijest mora biti očišćena religioznih natruha ... Uz glavno raskručivanje na svom putu, odbacujući idejne zablude i druge formalne razlike, socijalizam sadržajno određen uslovljava i izgrađuje cjelinu socijalističkog jedinstva. Ideologije tuđe socijalizmu - religija i sl. štete i bez vrijednosti su. Socijalizam, negacija prethodne stvarnosti, nužno postaje negacijom odgovarajućih do tada idejnih vrijednosti. Religija, kao neprovediva u život, svoje ideje o iluzornom životu mora zamijeniti idejama o stvarnom životu... $\ll^{32}$

Dakle u dvije trećine članaka u kojima se pojavljuje pojam religija (religioznost) uočava se njezino prezentiranje kao ideologije suprotstavljene izgradnji cjeline socijalističkoga jedinstva, odnosno predstavlja ju se kao proizvod prošlosti koji se svojim »zastarjelim objašnjenjem prirode i čovjeka može u socijalizmu prepustiti jedino prirodnom ishlapljivanju $\ll^{33}$

Preostali članci u okviru kojih se pojavljuje pojam religija (religioznost) jesu članci u kojima se izvještava o aktivnostima Općinskoga komiteta SKH-a Vinkovci, Narodne omladine, Socijalističkoga saveza radnoga naroda (SSRN) i slično. Riječ je najčešće o izvještavanju o održanim predavanjima, seminarima, odnosno društvenopolitičkim akcijama teritorijalnih osnovnih organizacija Saveza komunista koje su imale za cilj ideološko obrazovanje radnika i mladih. Članci čije je glavno obilježje »prenošenje službenih stajališta narodnoj masi « ${ }^{34}$ u najvećem se broju odnose na

${ }^{31}$ Dostupno na: http://library.foi.hr/vl/broj.aspx?C=10\&godina=1956\&broj=000045\&stranica=001 (21.5. 2020.).

${ }^{32}$ Dostupno na: http://library.foi.hr/vl/broj.aspx?C=10\&godina=1956\&broj=000047\&stranica=001 (22.5.2020.).

${ }^{33}$ Isto.

${ }^{34}$ K. SPEHNJAK, Uloga novina u oblikovanju javnog mnijenja u Hrvatskoj 1945. - 1952., 168. 
izvještavanje o $\gg$ radu na ideološko-političkom uzdizanju Narodne omladine $\ll^{35}$ radi njihova $\gg$ društveno-moralnog odgoja $\ll^{36}$, odnosno ideološko-političkom uzdizanju omladine i prosvjetnih djelatnika:

»Omladina koji živi u organizaciji gdje je zapušten ideološko-politički rad kao stalna forma uzdizanja omladinskog kadra - sklona je raznim nezdravim, konzervativnim i socijalizmu stranim shvatanjima. - Kao posljedica nedovoljnog ideološkog rada javlja se malograđanština i religioznost, jer se omladini ne ukazuje na te negativne uticaje, kojima je neophodno suprotstaviti napredno, marksističko shvatanje, kao pravilno za formiranje moralnog lika mladog čovjeka. $\ll{ }^{37}$

\subsection{KONTEKST POJAVLJIVANJA KLJUČNOGA POJMA CRKVA/CRKVENI}

Sljedeći analizirani pojam jest pojam crkva ili Crkva (crkvenost, crkveni i sl.) koji se među analiziranim ključnim riječima najučestalije pojavljivao te je uočen u ukupno 199 članaka. U jednoj četvrtini članaka u kojima se pojavljuje taj ključni pojam riječ je o člancima u kojima se pojam crkva, kao sakralna građevina, samo usputno spominje (52), primjerice navođenjem crkve koja je lokacijski smještena uz izvještavanje o nekoj aktivnosti o kojoj je riječ u članku, na primjer izgradnji parkirališta u blizini crkve i slično. Potom se uočavaju članci u kojima se o crkvama progovara u kontekstu govora o prošlosti vinkovačkoga kraja (51), koji se u najvećoj mjeri odnose na Crkvu kao instituciju, na primjer u kontekstu govora o crkvenoj literaturi $\gg$ kao historijskom materijalu o gledištu crkvenih organizacija prema ženi, obitelji i problemima u braku i odnosu u braku $\ll,{ }^{38}$ o arhivskim spisima koji potvrđuju da je Crkva bila $\gg$ čuvar okrutnog režima $\ll,{ }^{39}$ o prošlim crkvenim običajima, $\mathrm{o} \gg$ borbi protiv laži crkvene skolastičke učenosti $\ll,{ }^{40} \mathrm{o} \gg$ srednjovjekovnoj Crkvi zasnovanoj na mitu i magiji $\ll,{ }^{41}$ o utjecaju na razvitak školstva i općenito društvenoga uređenja:

${ }^{35}$ Dostupno na: http://library.foi.hr/vl/broj.aspx?C=10\&godina=1956\&broj=000043\&stranica=001 (20.5.2020.).

${ }^{36}$ Isto.

${ }^{37}$ Dostupno na: http://library.foi.hr/vl/broj.aspx? $\mathrm{v}=1 \& \mathrm{t}=1 \& \mathrm{z}=567 \& \mathrm{C}=10$ \&godina=1956\&broj= $000039 \&$ stranica $=002 \& u=$ religi $(22.5$. 2020.).

${ }^{38}$ Dostupno na: http://library.foi.hr/vl/broj.aspx?C=10\&godina=1957\&broj=000010\&stranica=001 (23.5.2020.).

${ }^{39}$ Dostupno na: http://library.foi.hr/vl/broj.aspx?C=10\&godina=1959\&broj=000007\&stranica=001 (23. 5. 2020.).

${ }^{40}$ Dostupno na: http://library.foi.hr/vl/broj.aspx?C=10\&godina=1960\&broj=000028\&stranica=001 (23. 5. 2020.).

${ }^{41}$ Isto. 
$\gg$ Bijedni Srednji vijek sa svojom crkvenom filozofijom i praznim dogmama-učenjima crkvenih otaca, kada nije bilo slobodne misli, a filozofija, kao sluškinja teologije, uz pomoć logike trebala je da dokaže istinitost crkvenih dogmi, onoga protiv čega su se borili pošteni mozgovi, osuđivani poslije toga i spaljivani. $\ll{ }^{42}$

U preostalim člancima u kojima se spominje crkva kao građevina, a vežu se uz prošlost vinkovačkoga kraja, crkve se nastoji prikazati kao objekte u kojima su se skrivali ustaše, ${ }^{43}$ odnosno u kojima se prikazuje crkvene službenike kao $\gg$ ustaške dušobrižnike $\ll^{44}$, ili se progovara o tome kako su $\gg$ ustaše odvodili zatočenike u crkvu $\ll{ }^{45}$ ili kako su $\gg$ ustaše držali tri dana leševe da vise pred crkvom. ${ }^{46}$

Uz članke u kojima se o katoličkim crkvama progovara u kontekstu prikazivanja prošlosti vinkovačkoga kraja pribraja se i serija članaka pod nazivom Iz prošlosti Vinkovaca. U njima se najčešće govori o vinkovačkoj crkvi na Meraji, ${ }^{47}$ za koju se iznose mnogobrojne informacije te se spominje u nekoliko članaka u kontekstu govora o podrijetlu imena grada Vinkovaca, ${ }^{48}$ ali i u kontekstu arheoloških nalazišta i važnosti zaštite crkve kao sakralnoga spomenika (1965.).

Crkva na Meraji spominje se i u okviru treće skupine članaka, koja se odnosi na govor o crkvama u tadašnjem suvremenom dobu, koju čine svi preostali članci u kojima se spominje taj pojam, a među kojima se u najvećem broju progovara o crkvama kao sakralnim građevinama u kontekstu njihova isticanja kao spomenika kulture, koji iziskuju poštovanje i zaštitu od propadanja.

Uz članke koji progovaraju o crkvama kao spomenicima kulture, u člancima koji se vezuju uz tadašnje aktualno vrijeme jedan se dio članaka odnosi i na govor o crkvenim objektima koji su pretrpjeli oštećenja od potresa koji se dogodio 13. trav-

${ }^{42}$ Dostupno na: http://library.foi.hr/vl/broj.aspx?C=10\&godina $=1956 \&$ broj=000043\&stranica=001 (23. 5. 2020.).

${ }^{43}$ Usp.http: / /ibrary.foi.hr/vl/broj.aspx?v=1\&t=1\&z=518\&C=10\&godina=1966\&broj=000052\&s tranica $=003 \& u=\operatorname{crkv}(24.5 .2020$. $)$.

${ }^{44}$ Dostupno na: http://library.foi.hr/vl/broj.aspx?v=1\&t=1\&z=518\&C=10\&godina=1966\&broj= $000005 \&$ stranica $=002 \& u=d u \% C 5 \% A 1$ obri\%C5\%BEnik (24. 5. 2020.).

${ }^{45}$ Dostupno na: http://library.foi.hr/vl/broj.aspx?C=10\&godina=1961\&broj=000052\&stranica=001 (24. 5. 2020.).

${ }^{46}$ Dostupno na: http://library.foi.hr/vl/broj.aspx?C=10\&godina $=1961 \&$ broj=000020\&stranica $=001$ (24. 5. 2020.).

${ }^{47}$ Usp. http://library.foi.hr/vl/broj.aspx? $\mathrm{v}=1 \& \mathrm{t}=1 \& \mathrm{z}=518 \& \mathrm{C}=10 \&$ godina $=1966 \& \mathrm{broj}=000049 \& \mathrm{~s}$ tranica $=006 \& u=$ meraj $(24.5$. 2020.).

${ }^{48}$ Usp. http://library.foi.hr/vl/broj.aspx?v=1\&t=1\&z=567\&C=10\&godina=1969\&broj=000001\&s tranica $=005 \& u=c r k v(25.5 .2020$.). 
nja 1964. godine na širem vinkovačkom području, dok se preostali članci vežu uz informiranje o održanim predavanjima članovima Saveza komunista, primjerice o održanoj raspravi komunista u Vođincima o tome $\gg$ kako je moguće da član SK bude čovjek koji prisustvuje svim sastancima osnovne organizacije ali i svim crkvenim obredima $\ll^{49}$. Slična izvještavanja o održanim predavanjima pojavljuju se tijekom svih istraživanih godina, primjerice o predavanju o zloupotrebi crkve i religije (1952.), o odnosu Crkve i države (1953.), o »Crkvi u suvremenom svijetu i nekim aktualnim političkim pitanjima vezanim za fenomen religije« (1967.), a spomenut će se i u govoru o drugim pretraživanim pojmovima.

\subsection{KONTEKST POJAVLJIVANJA KLJUČNOGA POJMA SVEĆENICI}

Sljedeći pretraživani pojam, svećenici, pojavljuje se u odabranom razdoblju u ukupno 73 članka. Uz članke u kojima se pojam svećenici spominje u kontekstu prenošenja informacija o doprinosima svećenika - od osobnoga dohotka od intelektualnih usluga ( 5 članaka), zahvala građana na iznesenim riječima na posljednjim ispraćajima pokojnika ( 8 članaka), u sklopu križaljki (6 članaka) - preostale je članke moguće podijeliti u dvije skupine: na one u kojima se izvještava o aktivnostima Pododbora staleškog društva katoličkih svećenika vinkovačkog kotara, izraženih u razdoblju od 1956. do 1962. godine (14 članaka), te na sve preostale članke u kojima se o svećenicima progovara u negativnom kontekstu, primjerice o zločinima svećenika za vrijeme Drugoga svjetskoga rata (1954.), o reakcionarnim svećenicima (1955.), o zloupotrebi propovjedaonice (1956.), zastrašivanju omladine (1956.), o suradnicima fašista (1966.).

U jednom od članaka kojima se promiče rad Pododbora staleškoga društva katoličkih svećenika vinkovačkoga kotara te njegova suradnja s državnom vlasti, simboličnoga naslova Kad bi svi tako, navodi se sljedeće:

$\gg$ Krajem prošlog mjeseca održana je u Vinkovcima godišnja skupština Kotarskog pododbora Društva katoličkih svećenika Vinkovci, kojoj su kao gosti prisustvovali brojni predstavnici nekih drugih pododbora Društva katoličkih i Udruženja pravoslavnih sveštenika Hrvatske i Srbije, kao i predstavnik Kotarskog Narodnog odbora. Bio je to jedan od onih skupova, koje zbog njihovog sadržaja i kvalitetnog rada treba posebno istaći. Ni na jednoj dosadašnjoj skupštini nije naime došla toliko do izražaja solidarnost članova Društva katoličkih svećenika s općim nastojanjima na unapređenju raznih područja života naših građana, a koja su

\footnotetext{
${ }^{49}$ Dostupno na: http://library.foi.hr/vl/broj.aspx? $=1 \& \mathrm{t}=1 \& \mathrm{z}=518 \& \mathrm{C}=10$ \&godina=1966\&broj= 000030\&stranica $=002 \& \mathrm{u}=\mathrm{crkv} ; \mathrm{http}: / /$ library.foi.hr/vl/broj.aspx? $\mathrm{v}=1 \& \mathrm{t}=1 \& \mathrm{z}=518 \& \mathrm{C}=10 \& \mathrm{go}$ dina $=1966 \& b r o j=000031 \&$ stranica $=001 \& u=\operatorname{crkv}(25.5$. 2020.).
} 
sadržana u programima organizacije SSRNJ i drugih političkih i društvenih organizacija, kao i težnja za suradnjom s Udruženjem pravoslavnih sveštenika na širenju i jačanju bratstva i jedinstva ... « $\ll^{50}$

\subsection{Kontekst POJAVlJIVANJA KLJUČNOGa POJMA KLER}

U člancima u kojima se pojavljuje pojam kler/klerikalizam (ukupno 26 članaka) u najvećem je broju riječ o govoru o negativnu utjecaju klera na omladinu. Tako članak iz 1952. godine progovara o važnoj ulozi koja se pridavala $\gg$ Narodnoj omladini u razvijanju kolektivne socijalističke svijesti (...) koja mora biti stalna, živa i intenzivna jer se ne smije dopustiti da se omladina truje klerikalizmom i nazadnim shvatanjima $\ll^{51}$.

U tim člancima, koji upozoravaju na važnost koja se pridavala obrazovnom sustavu, odnosno političko-ideološkom odgoju i obrazovanju mladih i pritom upućivanju na negativan utjecaj koji u procesu unaprjeđivanja odgojne funkcije škole može imati kler, konstanta je koja se pojavljuje u cjelokupnom promatranom razdoblju i obilježje je rezultata istraživanja za većinu analiziranih ključnih pojmova, ne samo kler već i religiju, religioznost, svećenike, vjeru itd. Važnost koja se $u$ »procesu preobrazbe društva $\ll^{52}$ pridavala kulturi i prosvjeti tema je mnogobrojnih članaka, među kojima se $u$ onima $u$ kojima se pojavljuje pretraživani pojam kler iste naziva »kočničarima za napredak « (1952.), koji će i »ubuduće nastojati ometati socijalističku izgradnju i udarati na bratstvo i jedinstvo naših naroda, kao jednu od najvećih tekovina socijalističke Jugoslavije. Zato organizacija Saveza komunista mora otvorenije, nego je to do sada činila, istupati, raskrinkavajući na konkretnim pitanjima rad neprijateljskih elemenata. $\ll{ }^{53}$

Borba protiv $\gg$ malograđanskog utjecaja klerikalizma $\ll{ }^{54}$ također je dio sveobuhvatne politike usmjerene i prema prosvjetnim djelatnicima koja je obuhvaćala promicanje »obveze prosvjetnih radnika da odgajaju omladinu u socijalističkom duhu, a

${ }^{50}$ Dostupno na: http://library.foi.hr/vl/broj.aspx?C=10\&godina=1960\&broj=000028\&stranica=001 (25. 5. 2020.).

${ }^{51}$ Dostupno na: http://library.foi.hr/vl/broj.aspx?C=10\&godina=1952\&broj=000009\&stranica=001 (25.5. 2020.).

${ }^{52}$ I. BENDRA, D. ŽIVIĆ, P. ELEZ, Položaj vjerskih zajednica u Općini Vinkovci (1964. - 1975.), 221.

${ }^{53}$ Dostupno na: http://library.foi.hr/vl/broj.aspx?v=1\&t=1\&z=567\&C=10\&godina=1955\&broj= $000017 \&$ stranica $=001 \& u=\operatorname{kler}(25.5$. 2020.).

${ }^{54}$ Dostupno na: http://library.foi.hr/vl/broj.aspx?C=10\&godina $=1952 \& b r o j=000003 \&$ stranica $=001$ (25. 5. 2020.). 
nazadan, klerikalan ili neprijateljski nastrojen učitelj $\ll{ }^{55}$ nije mogao biti odgojitelj mladih.

Uz članke u kojima se progovara o »utjecaju nazadnih elemenata klera na školsku omladinu $\ll^{56}$ te članaka u kojima se progovara o $\gg$ upitnom ostvarenju socijalističkih odgojnih principa $\mathrm{u}$ nastavi $\ll^{57}$ kod onih prosvjetnih radnika koji održavaju veze s klerom te idu u crkvu, značajan je i broj članaka u kojima se progovara o zločinima koje je jedan dio katoličkoga klera u Hrvatskoj počinio za vrijeme Drugoga svjetskoga rata. ${ }^{58}$

\subsection{KONTEKST POJAVLJIVANJA KLJUČNOGA POJMA SLOBODA VJEROISPOVIJESTI}

Sljedeći ključni pojam, sloboda vjeroispovijesti, pojavljuje se u pretraživanom razdoblju u svega trima člancima. Riječ je o člancima u kojima se navodi kako je, unatoč tomu što je Ustavom iz 1963. godine i Zakonom iz 1953. godine građanima zajamčeno pravo na slobodu vjeroispovijesti, ipak potrebno voditi računa o tome da to isto pravo ne ometa daljnji nesmetani razvoj socijalističkoga društva. Tako se u članku iz 1967. godine, naslovljenom Omladina Gimnazije o svojim zadacima Glavna tema-samoupravljanje, progovara o aktualnim problemima gimnazijalaca te se, među ostalim, navodi kako je »jedan od budućih zadataka SO problem utjecaja Crkve na učenike jer iako je Ustavom zagarantirana sloboda ispovijedanja vjere škola ne može dozvoliti da se omladinac opterećuje fantastičnim odnosima Crkve prema stvarnosti, omladinca treba odgajati u naučnom duhu. $\ll^{59}$

\subsection{KONTEKST POJAVLJIVANJA KLJUČNOGA POJMA VJERA}

Pretraživani pojam vjera (vjernici, vjeronauk) u istraživanom razdoblju pojavljuje se u ukupno 45 članaka. U jednom dijelu članaka u kojima se spominje taj pojam također se progovara o prošlosti vinkovačkoga kraja te se uočava kako se pojam vjera (vjeroispovijed i sl.) pojavljuje u kontekstu govora o negdašnjim običajima u

${ }^{55}$ Dostupno na: http://library.foi.hr/vl/broj.aspx?C=10\&godina=1952\&broj=000003\&stranica=001 (26.5. 2020.).

${ }^{56}$ Dostupno na: http://library.foi.hr/vl/broj.aspx?C=10\&godina=1953\&broj=000023\&stranica=001 (26.5.2020.).

${ }^{57}$ Dostupno na: http://library.foi.hr/vl/broj.aspx?C=10\&godina=1954\&broj=000027\&stranica=001 (26. 5.2020.).

${ }^{58}$ Usp. http://library.foi.hr/vl/broj.aspx $? \mathrm{C}=10$ \&godina=1954\&broj=000044\&stranica=001 (25. 5 . 2020.).

${ }^{59}$ Dostupno na: http://library.foi.hr/vl/broj.aspx?v=1\&z=567\&C=10\&godina $=1967 \&$ broj=00001 $4 \&$ stranica $=004 \& u=$ slobod $(4.6 .2020$.). 
vinkovačkom kraju, primjerice o početcima obrazovnoga sustava (1953./1954.), o vjerskim svečanostima (1964.) ili o tome kako su nekada najviše bile izražene vjerske suprotnosti (1955.). Isto tako može se uočiti kako se u tim člancima u kojima se spominje pojam vjera, a tiču se prošlosti vinkovačkoga kraja, kršćanska vjera također kontinuirano dovodi na raznorazne načine u svezu s tekstovima u kojima se tematski progovaralo o razdoblju postojanja Nezavisne Države Hrvatske.

Članci u kojima se pojam vjera pojavljuje u kontekstu govora o aktualnom vremenu u najvećem se broju odnose na članke koji progovaraju o radu općinske Komisije za vjerske poslove, primjerice izvještavaju o novogodišnjem prijemu predstavnika vjerskih zajednica kod predsjednika Općinske skupštine (1965., 1966.) ${ }^{60}$ ili prenose informaciju iz Osnovnoga zakona o radnim odnosima prema kojemu je radnicima bilo omogućeno korištenje jednoga dana godišnjega odmora u vremenu kada to radnik želi, primjerice za neke vjerske svetkovine (1970.). U preostalim člancima u kojima se spominje pojam vjera riječ je o govoru o održavanju vjerskih obreda u nedozvoljenim stambenim objektima (1955.), o donesenom Zakonu o pravnom položaju vjerskih zajednica 1953. godine kojim su »regulisana sva prava i dužnosti građana, bez obzira na socijalnu, nacionalnu, političku ili vjersku pripadnost, garantujući im potpunu ravnopravnost, kako na političkom, tako i na ekonomskom i kulturno-prosvjetnom polju $\ll^{61}$ ili o Titovu ukidanju ograničenja koja su u prošlosti postojala, a koja su se temeljila na vjerskoj pripadnosti (1957.). Isto tako 1959. godine pojavljuje se članak u kojem se izvještava o presudi katoličkom svećeniku na 18 mjeseci zatvora zbog zloupotrebe slobode obavljanja vjerskih obreda, odnosno zbog iznošenja kritika na socijalistički oblik društvenoga uređenja. Također 1960. godine prenosi se informacija o kršenju Zakona o pravnom položaju vjerskih zajednica i suđenju $\gg$ proustaškoj skupini bogoslova i poglavaru iz Đakova « s kaznom od 7 godina zatvora zbog, kako se navodi, $\gg$ sistematskog neprijateljskog djelovanja i utjecanja na okolinu $\ll .{ }^{62} \mathrm{U}$ istom članku također se navodi kako je unatoč djelovanju optuženih svećenika protiv društvenoga uređenja zaslugom Društva katoličkih svećenika spriječeno zatvaranje bogoslovije, sjemeništa i liceja visoke bogoslovne škole u Đakovu. Također u više se članaka spominje i potreba intenzivnijega razvi-

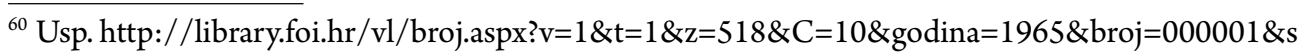
tranica $=001 \& \mathrm{u}=$ vjersk; http: / /library.foi.hr/vl/broj.aspx? $\mathrm{v}=1 \& \mathrm{t}=1 \& \mathrm{z}=518 \& \mathrm{C}=10$ \&godina $=196$ $6 \&$ broj $=000001 \&$ stranica $=001 \& u=v j e r s k(22.5 .2020$. $)$.

${ }^{61}$ Dostupno na: http://library.foi.hr/vl/broj.aspx?C=10\&godina=1955\&broj=000029\&stranica=001 (23.5. 2020.).

${ }^{62}$ Dostupno na: http://library.foi.hr/vl/broj.aspx?C=10\&godina $=1960 \&$ broj=000007\&stranica $=001$ (24. 5. 2020.). 
janja zabavnoga života mladih, zbog čijega je nedostatka $\gg$ infiltriran utjecaj vjerskih zajednica na njihov odgoj ${ }^{63}$.

\subsection{KONTEKST POJAVLJIVANJA KLJUČNOGA POJMA KRŠĆANSTVO}

Pojam kršćanstvo pojavljuje se u analiziranom razdoblju u svega 24 članka. U najvećem broju riječ je o člancima u kojima se progovara o prošlosti vinkovačkoga kraja, primjerice o ranokršćanskim spomenicima (1956.) ili o doseljavanju kršćana na vinkovačko područje (1959.). Također pojam kršćanstvo pojavljuje se i u kontekstu govora o $\gg$ kršćanskom ustaškom kleru « (1966.) ${ }^{64}$ o kršćanskom kleru kao pomagačima u okupatorskim logorima (1966.), o kršćanskoj mitologiji (1967.), o svećenicima koji rade na štetu Crkve i kršćanskoga naroda (1955.). Znakoviti su i feljtoni Novosti - sujevjerje u prošlosti $i$ danas pod specifičnim naslovom Vještice u vijeku atoma i osvajanja kozmosa koji su se pojavljivali u nastavcima, a koji su imali za cilj prikazivati kler, kršćanstvo i religiju na negativan način, kao ostatke prošlosti, predstavljajući kršćanstvo kao netolerantnu konkurenciju te izjednačavajući je $\mathrm{s}$ mistikom i vračanjem. ${ }^{65}$

\subsection{KonTEKST POJAVLJIVANJA KLJUČNOGA POJMA KATOLIČANSTVO/KATOLICI}

Posljednji analizirani pojam, pojam katoličanstvo, pojavljuje se u ukupno 44 članka. Prvi put pojavljuje se 1952. godine u dvama člancima, jednom o književnoj literaturi iz prošlosti religioznoga sadržaja te u drugom pod naslovom Prosvjetni radnici kotara i grada Vinkovci osuduju stav Vatikana prema našem narodu, u kojemu se izvještava o održanom referatu Religija $i$ odgoj. U izvještaju o predavanju o društveno-moralnom odgoju u školama $i$ »provokativnom postupku Vatikana postavljajući Stepinca za kardinala « navodi se kako su prosvjetni radnici donijeli sljedeću rezoluciju na spomenutom događanju:

>Danas, kada se čitava naša javnost zgraža nad provokativnim stavom Vatikana imenovanjem Stepinca za kardinala i mi prosvjetni radnici grada i kotara Vinkovaca pridružujemo se negodovanju čitavog našeg naroda i najenergičnije osuđujemo neprijateljsku politiku Vatikana prema

${ }^{63}$ Dostupno na: http://library.foi.hr/vl/broj.aspx?C=10\&godina=1961\&broj=000047\&stranica=001 (24. 5. 2020.).

${ }^{64}$ Dostupno na: http://library.foi.hr/vl/broj.aspx? $\mathrm{v}=1 \& \mathrm{t}=1 \& \mathrm{z}=567 \& \mathrm{C}=10$ \&godina=1966\&broj= $000005 \&$ stranica $=002 \& u=\mathrm{kr} \% \mathrm{C} 5 \% \mathrm{~A} 1 \% \mathrm{C} 4 \% 87$ (4. 6. 2020.).

${ }^{65}$ Usp. M. M. PISEK, Crkva i država - procesi (de)sekularizacije, 2014., Ljubljana. 
našoj zemlji. To je još jedan od mnogih dokaza iz naše historije, kako je Vatikan uvijek radio protiv interesa slobode i časti našega naroda. ${ }^{66}$

Sljedeće godine (1953.) pojavljuje se jedan članak o katoličkim svećenicima u okviru kojega se progovara o stavu dijela katoličkih svećenika o donesenom Zakonu o pravnom položaju vjerskih zajednica, odnosno u okviru kojega se također promiče rad Društva katoličkih svećenika:

»Narodna skupština je donijela između ostalih zakona onaj i o pravnom položaju vjerskih zajednica, kojim je demokratski riješen i postavljen problem vjerskih zajednica u našoj domovini. Na temelju našeg ustava i u ime slobode savjesti - slobodno je osnivati i pripadati kojoj vjerskoj zajednici, no i njihovi pripadnici su naši građani i imaju se pridržavati naših zakona i biti lojalni građani. To se nekim, naročito starijim po šarži katoličkim svećenicima, ne dopada, i stalno drže oko i uho otvoreno za vanjske utjecaje i sugestije i to baš takovih krugova, koji ne žele sređenje prilika u našoj domovini radi svojih apetita, a to nije dobro i ne može dobro svršiti za njih. To dobro vide i shvaćaju oni svećenici, koji vole svoju zemlju, koji su patrioti, pa su to dokazali za vrijeme Narodno-oslobodilačke borbe i poslije oslobođenja u konstruktivnoj saradnji s narodnim vlastima i koji sada osnivaju svoje svećeničko udruženje, što im naš zakon dozvoljava kao našim građanima. $\ll^{67}$

Godine 1954. pojavljuje se samo jedan, već spomenuti, članak o katoličkom kleru koji je za vrijeme Drugoga svjetskoga rata počinio brojne zločine, dok se 1956. godine pojavljuje najveći broj članaka, njih ukupno sedam. Dva se odnose na informiranje o aktivnosti Kotarskoga odbora Staleškoga društva katoličkih svećenika, jedan na zloupotrebu propovjedaonice za klevetanje društvenoga uređenja, zbog čega je katolički svećenik dobio kaznu zatvora od jedne godine i šest mjeseci, a preostali na izvještavanje o slabljenju utjecaja Katoličke Crkve izvan Jugoslavije (Francuska, Engleska, Španjolska i Nizozemska). Također članci koji se pojavljuju tijekom 1958., 1960., 1961. i 1962. godine odnose se na izvještavanje o aktivnostima Društva katoličkih svećenika. Preostali članci jesu oni u kojima se o katoličkim svećenicima ili katoličkim crkvama govori u kontekstu prošlosti vinkovačkoga kraja.

${ }^{66}$ Dostupno na: http://library.foi.hr/vl/broj.aspx?v=1\&z=518\&C=10\&godina=1952\&broj=00001 $5 \&$ stranica $=002 \& u=$ katoli\% $4 \% 8 \mathrm{Dk}$ (3. 6. 2020.).

${ }^{67}$ Dostupno na: http://library.foi.hr/vl/broj.aspx?v=1\&z=567\&C=10\&godina=1953\&broj=00003 $6 \&$ stranica $=001 \& u=s v e \% C 4 \% 87$ en $(2.6 .2020$.). 


\section{Zaključna promišljanja o odnosu tiska prema Katoličkoj Crkvi u razdoblju od 1952. do 1970. godine na temelju analize vinkovačkoga lista Novosti}

Promjene u odnosu tiska prema Katoličkoj Crkvi u razdoblju od 1952. do 1970. godine u ovom su radu utvrđivane na temelju rezultata kvantitativno-kvalitativne analize članaka objavljenih u vinkovačkom listu Novosti. Sva slojevitost koja je postojala u odnosu tiska prema toj vjerskoj zajednici u odabranom razdoblju promatrana je u odnosu na učestalost pojavljivanja te kontekst u kojem su izrečeni sljedeći ključni pojmovi: religija/religioznost, katoličanstvo (Katolička Crkva / katolici), kršćanstvo/kršćani, crkva, vjera (vjerski/vjeronauk), kler/klerikalizam, svećenici te sloboda vjeroispovijesti. Na temelju rezultata analize članaka lista Novosti vidljivo je kako se u člancima najučestalije pojavljivao pojam crkva (u 199 članaka), potom pojam svećenici (73 članka), religija/religioznost (64 članka), vjera (45 članaka), katolici / Katolička Crkva (44 članka), kler (26 članaka), kršćanstvo (24 članka), dok je pretraživani pojam sloboda vjeroispovijesti pojam koji se najrjeđe pojavljivao, u svega trima člancima.

Podatci o ukupnom broju članaka prema zadanim kriterijima potvrđuju neutralizaciju javnoga prostora, odnosno važnu zadanu $\gg$ ulogu novina u oblikovanju javnog mnijenja $\ll{ }^{68} \mathrm{u}$ vremenu stvaranja novoga socijalističkoga jugoslavenskoga društveno-političkoga uređenja. Isto tako podatci o učestalosti pojavljivanja odabranih ključnih pojmova u pretraživanom razdoblju, dugom devetnaest godina, većim dijelom potvrđuju i zadanu hipotezu da se u člancima vinkovačkoga lista Novost $i$ prema učestalosti pojavljivanja ključnih pojmova ne uočavaju nikakve promjene $\mathrm{u}$ odnosu tiska prema Katoličkoj Crkvi u istraživanom razdoblju. Iznimka je jedino 1956. godina kada je uočeno učestalije pojavljivanje većine ključnih pojmova.

$S$ druge strane rezultati kvalitativne analize članaka također su potvrdili zadanu hipotezu da se prema načinu izvještavanja vinkovačkoga lista Novosti o ključnim pojmovima u zadanom razdoblju ne uočavaju nikakve promjene. Rezultati analize tako su pokazali da se u okviru članaka u kojima se pretraživani ključni pojmovi pojavljuju uočava kontinuirano propagiranje sustava vrijednosti i ideja usklađenih sa službenom ideologijom te se u člancima, uglavnom izvještajima i komentarima, progovara o stavovima vladajućih organa o religiji, Crkvi i religioznosti te njihovim aktivnostima u suzbijanju utjecaja religije na razvitak socijalističkoga društva. $\mathrm{Uz}$ navedeno u okviru provedbe šire kulturne i prosvjetne politike, »koja je imala za cilj promjenu načina razmišljanja i pogleda na svijet $\ll^{69}$, članci oblikovani službe-

\footnotetext{
${ }^{68}$ K. SPEHNJAK, Uloga novina u oblikovanju javnog mnijenja u Hrvatskoj 1945. - 1952, 166.

${ }^{69}$ K. SPEHNJAK, Prosvjetno-kulturna politika u Hrvatskoj 1945. - 1948., 74.
} 
nom ideologijom imali su za cilj prikazivanje religije kao proizvoda prošlosti i korjenitu preobrazbu društva kroz protureligioznu kampanju.

Upravo je dakle na temelju istraživanja o učestalosti pojavljivanja pretraživanih pojmova, ali i sadržaja, odnosno konteksta njihova pojavljivanja u malobrojnim člancima u kojima se oni ipak navode, najizraženije uočena uvodno spomenuta slojevitost odnosa jugoslavenske vlasti prema vjerskim zajednicama, osobito Katoličkoj Crkvi, kao vjerskoj zajednici za koju se držalo da je imala »nemali utjecaj na vjernike pružajući im prostor za razmjenu kritičkih ideja i razmišljanja $\ll^{70}$, odnosno $\gg$ jedinim pravim oponentom jednostranačkom komunističkom režimu «. ${ }^{71} \mathrm{Iz}$ članaka se tako uočava kako, unatoč svim mijenama koje su se događale, od primjene administrativnoga tipa politike do njezine zamjene kooperativnim tipom politike, ${ }^{72}$ koja je posebice došla do izražaja potpisivanjem Protokola 1966. godine, ipak se cjelokupno analizirano razdoblje može promatrati kao cjelinu, »kao zaokruženo i u sebi neproturječno razdoblje povijesti Hrvatske $\ll \cdot{ }^{73}$ Nastojanje da se kroz novine, kao javni medij, obavlja transmisija idejno-političkoga tipa partijske politike koji »želi prožeti društvenu stvarnost uvjerenjem da je religija iskrivljena društvena svijest koju se može prevazići prosvjećivanjem i širenjem racionalno-znanstvenog pogleda na svijet i koja će odumrijeti ekonomskim razvojem i izgradnjom socijalističkih društvenih odnosa ${ }^{74}$ prisutno je u gotovo svim člancima u kojima se spominju pretraživane ključne riječi u cjelokupnom promatranom razdoblju.

Unatoč tomu što se donošenjem Zakona o pravnom položaju vjerskih zajednica 1953. godine Jugoslavija nastojala svrstati u red država s demokratskim uređenjem, članci iz vinkovačkoga lista Novosti pokazuju drukčije stvarno stanje. Članci tako pokazuju kako je stvarni položaj Katoličke Crkve, u odnosu na normativan, u skladu s materijalističkim pogledom na svijet, unatoč Zakonom o pravnom položaju vjerskih zajednica (1953.) i Ustavom iz 1963. godine donesenim pravima, obilježavalo nastojanje jugoslavenske vlasti da u što većoj mjeri nadzire djelovanje Katoličke Crkve kako bi se smanjio njezin utjecaj u društvu te toleriranje njezina rada jedino kroz rad Društva katoličkih svećenika. Promatrajući rezultate pojedinačno za odabranu ključnu riječ svećenici, možemo uočiti kako su novine bile u službi ostvarenja završetka procesa diferencijacije, kojemu je trebalo pridonijeti promicanje učlanjenja svećenika u Društvo katoličkih svećenika, i njegova omasovljenja.

\footnotetext{
${ }^{70}$ K. BOECKH, Vjerski progoni u Jugoslaviji 1944. - 1953.: staljinizam u titoizmu, 407.

${ }^{71}$ M. AKMADŽA, Biskup Stjepan Bauerlein i crkveno-državni odnosi do 1966. godine, u: VDG Jahrbuch - godišnjak njemačke narodnosne zajednice 1(2007.), 47-69., ovdje 47.

${ }^{72}$ Usp. S. ZRINŠČAK, Odnos Crkve i države u Hrvatskoj od 1945. - 1990. godine, 114-119.

${ }^{73}$ Isto, 107.

${ }^{74}$ Isto, 123.
} 
Udruženja katoličkih svećenika, »čiji je osnutak pod Titom bio potpomagan «,75 trebala su $\gg$ služiti jačanju državnoga utjecaja te omogućiti razlikovanje između državi lojalnih i nenaklonjenih svećenika ${ }^{76} \mathrm{i} \gg$ odcijepiti niži kler od višeg, pretežno antikomunistički nastrojenoga klera, i preusmjeriti njihovu energiju na izvršavanje društvenih zadaća ${ }^{77}$. Stoga se na temelju analize članaka tjednika Novosti može zaključiti kako su se u unutardržavnom odnosu države i Katoličke Crkve društva katoličkih svećenika držala ključnima za daljnji tijek ostvarenja normalizacije odnosa između te vjerske zajednice i države. ${ }^{78}$ Članci također pokazuju kako se tzv. kooperativna politika na lokalnoj razini odražavala na način da se kroz tisak pozitivno odnosilo jedino prema onim predstavnicima Katoličke Crkve koji su pristali na suradnju s državom, dajući legitimitet novom socijalističkom društvenom uređenju učlanjenjem u svećenička udruženja, dok se za sve ostale neprestano upozoravalo na njihovo držanje za vrijeme postojanja Nezavisne Države Hrvatske, odnosno nastojalo ih se prikazati »pomagačima ustaša «. Na taj način Katolička Crkva prikazivala se kao suradnica okupatora, čime su »novine, kao javni medij, postale snažno sredstvo indoktrinacije $\ll^{79}$

Kontinuirani naglasak na protureligioznoj propagandi, predstavljanju ideološkopolitičkoga rada društveno-političkih organizacija u borbi protiv utjecaja religije na razvitak jugoslavenskoga socijalističkoga društva, na promicanju rada Društva katoličkih svećenika, na depolitizaciji Crkve i klerikalizmu, posebice na prekoračenju u obavljanju vjerskih poslova zbog negativnoga ideološkoga utjecaja kroz katehizaciju mladih, upozorava na konstantu u odnosu tiska prema religiji, Crkvi i vjerskim zajednicama, dok s druge strane potvrđuje kako je razdoblje kooperativnosti i pragmatičnoga tipa politike prema Katoličkoj Crkvi najviše pozitivnoga odjeka imalo u pogledu odnosa SFRJ-a i Svete stolice, dok je u unutardržavnom odnosu ostavilo i dalje neriješena upravo ona pitanja na koja su biskupi i stavljali najviše naglasak tijekom započeta tzv. procesa normalizacije odnosa. Unatoč promijenjenoj vanjskoj politici i pristupu prema Katoličkoj Crkvi, konstantu u odnosu tiska prema toj vjerskoj zajednici potvrđuje opetovano upućivanje na klerikalizam za svako djelovanje Katoličke Crkve na izgradnji vjerske zajednice utemeljene na postkoncilskom duhu, odnosno neprestano onemogućavanje katehizacije djece i mladih,

\footnotetext{
${ }^{75}$ Usp. K. BOECKH, Vjerski progoni u Jugoslaviji 1944. - 1953.: staljinizam u titoizmu, 422.; I. BENDRA, D. ŽIVIĆ, P. ELEZ, Položaj vjerskih zajednica u Općini Vinkovci (1964. - 1975.), 255.

${ }^{76}$ K. BOECKH, Vjerski progoni u Jugoslaviji 1944. - 1953.: staljinizam u titoizmu, 422.

${ }^{77}$ Isto, 423.

${ }^{78}$ Usp. I. BENDRA, D. ŽIVIĆ, P. ELEZ, Položaj vjerskih zajednica u Općini Vinkovci (1964. 1975.),107-184.

${ }^{79}$ K. SPEHNJAK, Uloga novina u oblikovanju javnog mnijenja u Hrvatskoj 1945. - 1952., 168.
} 
kao i njihova prava na odgoj u vjeri kojoj pripadaju. Dakle, premda se potpisivanje Protokola držalo iznimno važnim za unapređenje odnosa između Katoličke Crkve i SFRJ-a, rezultati potvrđuju da je on prije svega pridonio SFRJ-u radi njezine $\gg$ afirmacije na vanjskom planu kao otvorene zemlje demokratskih načela $\ll^{80}$, odnosno upućuju na to da je njime izostalo rješavanje problema odgoja mladih, a na što su zapravo i stavljali naglasak jugoslavenski biskupi. ${ }^{81}$

Značajnu provedbu antireligiozne propagande kroz tisak, kao posljedicu uočena utjecaja Katoličke Crkve na djecu i mlade, pokazuju i izvještavanja o sustavnom i organiziranom idejno-političkom djelovanju među članovima SK-a u borbi za izgradnju socijalističkoga čovjeka i kontinuirano promicanje religije kao zablude, osuđene na odumiranje. Rezultati istraživanja time potvrđuju kako se ideološkopolitička borba koja se provodila za ostvarenje procesa smanjivanja utjecaja religije na razvitak novoga socijalističkoga društvenoga uređenja, primarno pomoću društveno-političkih i obrazovno-odgojnih organizacija, provodila i pomoću tiskanih javnih medija.

Dakle moguće je na primjeru analize lokalnoga tiska, vinkovačkoga tjednika Novosti, zaključiti kako je tzv. kooperativno razdoblje odnosa Katoličke Crkve i jugoslavenske vlasti, odnosno razdoblje u kojem je 50-ih i 60-ih godina prošloga stoljeća uslijedila normalizacija odnosa, prije svega jugoslavenske vlasti sa Svetom stolicom, zapravo, razdoblje nepromijenjenoga odnosa tiska prema Katoličkoj Crkvi. Premda se za to razdoblje drži da je došlo do određena poboljšanja položaja Katoličke Crkve, prije svega zbog smanjenja primjene represivnih mjera, do takvoga zaključka došlo se sveukupno promatrajući učestalost pojavljivanja odabranih ključnih pojmova, kao i sadržaj, odnosno kontekst u okviru kojega su se ključni pojmovi pojavljivali u vinkovačkom listu Novosti. Analizom razdoblja dugoga devetnaest godina došlo se do zaključka kako je odnos tiska prema Katoličkoj Crkvi odlikovala konstanta, koja je posljedica značajki odnosa socijalističkoga društvenoga uređenja prema vjerskim zajednicama. Činjenica da su u tadašnjem vremenu novine služile za oblikovanje $\gg$ javnog mnijenja u skladu s ideološkom predodžbom 'odgajanja

${ }^{80}$ M. AKMADŽA, Katolička crkva u komunističkoj Hrvatskoj 1945. - 1980., 380.

${ }^{81}$ Usp. I. BENDRA, D. ŽIVIĆ, P. ELEZ, Položaj vjerskih zajednica u Općini Vinkovci (1964. - 1975.). Šira analiza arhivskih spisa za vinkovačko područje, koju su objavili autori ove studije, a koja se jednim dijelom poklapa s razdobljem ovoga istraživanja, zapravo pokazuje kako se od 1966. godine, dakle nakon potpisivanja Protokola između Sv. Stolice i Jugoslavije i nadolazećega postkoncilskoga vremena uočava početak aktivnije provedbe idejno-političkih aktivnosti Komisije za vjerske poslove i društveno-političkih organizacija. Razdoblje od 1966. godine u potpunosti je posvećeno praćenju tzv. povećane aktivnosti klera, prije svega pastoralnih aktivnosti usmjerenih prema mladima i redovitom informiranju društveno-političkih organizacija i Komisije IVS-a o tome. 
masa' za socijalizam $\ll^{82}$ potvrđuje zadanu ulogu medija u odnosu prema Katoličkoj Crkvi za cjelokupno promatrano razdoblje, neovisno o početcima procesa liberalizacije medija 60-ih godina prošloga stoljeća koje navodi Mihaljević. Vinkovački list Novosti služio je dakle kao važno sredstvo utjecaja na javno mnijenje te je bio jedan od ključnih čimbenika za propagiranje sustava vrijednosti i ideja usklađenih sa službenom ideologijom.

${ }^{82}$ K. SPEHNJAK, Uloga novina u oblikovanju javnog mnijenja u Hrvatskoj 1945. - 1952., 166. 


\section{THE ATTITUDE OF THE PRESS TOWARDS THE CATHOLIC CHURCH IN YUGOSLAVIA IN THE PERIOD FROM 1952 TO 1970 - ON THE EXAMPLE OF THE ANALYSIS OF THE VINKOVCI NEWSPAPER NOVOSTI}

\section{Ivana BENDRA*}

Summary: The complexity of the Yugoslav communist government's attitude towards the Catholic Church under the creation of a new socialist socio-political system is the topic that will be discussed in this paper based on the analysis of the press's attitude towards the Catholic Church in the period from 1952 to 1970. Based on the quantitative-qualitative analysis of articles published in the Vinkovci newspaper Novosti in the selected period, we will show the frequency of occurrence results and the context in which the selected keywords for the analysis of the digital version of the newspaper appeared (Catholic Church, priests, religion/religiosity, clergy/clericalism, church, faith, Christianity). Thus, the analysis of the weekly Novosti aims to determine whether we can observe certain changes in the attitude of the press towards the Catholic Church over nineteen years, during which several events took place to question Yugoslavia's overall attitude towards the Catholic Church (from the severance of diplomatic relations between the Holy See and Yugoslavia, the signing of the Protocol, all the way to the re-establishment of diplomatic relations).

Keywords: Catholic Church, press, Vinkovci newspaper Novosti, Yugoslavia, quantitative-qualitative content analysis.

\footnotetext{
* Ivana Bendra, Ph. D., Institute of Social Sciences Ivo Pilar, Regional Center Vukovar, J. J. Strossmayera 25, P. O. box 58, 32000 Vukovar, Croatia, Ivana.Bendra@pilar.hr
} 